\title{
THE EXAMINATION OF THE CEREBROSPINAL FLUID AND CEREBRAL CYST FLUID BY PAPER STRIP ELECTROPHORESIS
}

\author{
BY \\ J. N. CUMINGS
}

From the Clinical Pathological Laboratory, The National Hospital, Queen Square, London

The application of the method of paper electrophoresis to the study of the serum proteins is now well established, but it has rarely been applied to the examination of the proteins of the cerebrospinal fluid (C.S.F.) and not at all to those of the fluids from cerebral cysts.

Schneider and Wallenius (1951) have recorded their results in 14 cases, five of which were normal, while more recently Wallenius (1952) examining a larger series was unable to come to any definite conclusions about pathological material, although he found that the normal C.S.F. protein pattern followed closely that of the blood pattern. Labhart, Schweizer, and Staub (1951) examined many fluids but used a microelectrophoretic technique and not the paper strip method. Schaltenbrand (1952) has also examined a large number of fluids. One of the difficulties experienced by some workers has been to obtain an adequate concentration of protein in the fluid.

This paper records the results obtained in an examination of 70 pathological cerebrospinal fluids and of 45 cyst fluids found in association with cerebral tumours. tubing acts as the anode. After application at the centre of a strip of Whatman No. 1 filter paper of 5 to 10 c.mm. of concentrated C.S.F. or of cyst fluid, 120-126 volts is applied overnight for 17 hours with a current consumption of 0.11 to $0.12 \mathrm{~mA}$ per $\mathrm{cm}$. width. After the usual drying and staining of the strips the excess bromphenol blue is removed by washing in running tap water. When dry they are rendered transparent by dipping in the following solution :

Tricresyl phosphate
Pet. ether B.P. $80-100^{\circ}$
Acetone

They are dried and the depth of colour per mm. width is read in a suitable photoelectric apparatus.

Preparation of Material.-Cerebral cyst fluid could practically always be used directly as for serum, but the protein content of the C.S.F., being low, needs concentration. Two methods have been used, and while both are satisfactory, the second is quicker. The fluid in each case is placed in a glass cylinder $3 \mathrm{~cm}$. wide, across the lower end of which is a cellophane membrane. The tube is half immersed in $20 \%$ "dextran," and sufficient concentration of the protein occurs in 24 to $\mathbf{7 2}$ hours at refrigerator temperature. Alternatively, the tube can be placed in $30 \%$ polyvinylpyrrolidone and concentration takes place either at room temperature or in the refri-

\section{Materials and Methods}

Seventy cerebrospinal fluids have been examined, three of which were obtained from the lateral ventricles while the remainder were lumbar fluids. Forty-five cerebral cyst fluids were obtained, 44 at operation and one at necropsy.

The apparatus used is illustrated in Fig. 1 and is somewhat similar to that described by Flynn and de Mayo (1951), but differs in that separate perspex jars are used, one pair for each strip, and instead of the usual carbon rod a piece of platinum wire sealed in glass

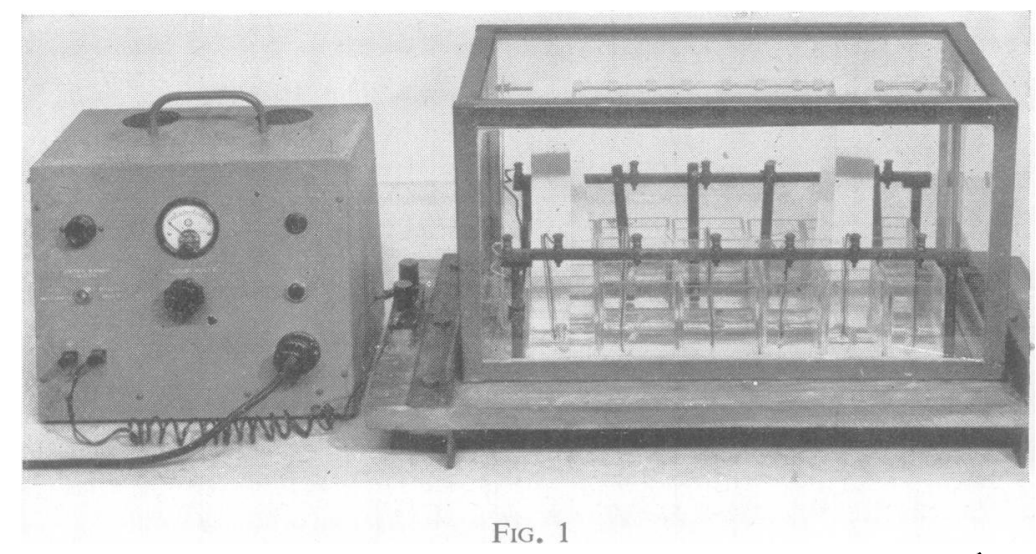


gerator in about 24 hours. The amount of fluid needed and the length of time of concentration required depend on the protein content of the C.S.F., usually between 3 and $10 \mathrm{ml}$. of C.S.F. being required. Both solutions need renewing fairly frequently, and " dextran" readily becomes infected at room temperature.

\section{Results}

Before consideration is given to the actual results obtained it might be useful to comment briefly upon the nature of the curves found using this method of examination. The type of protein pattern obtained from blood serum is illustrated by Fig. 2 from which it is seen that the largest component is albumin, and that it has travelled farthest towards the positive electrode, the direction of which is indicated by the arrow.

The $\gamma$ globulin fraction, on the other hand, migrates towards the negative electrode, but only to a point just beyond the site of application of the serum. The other globulin components are arranged between these two fractions as indicated.

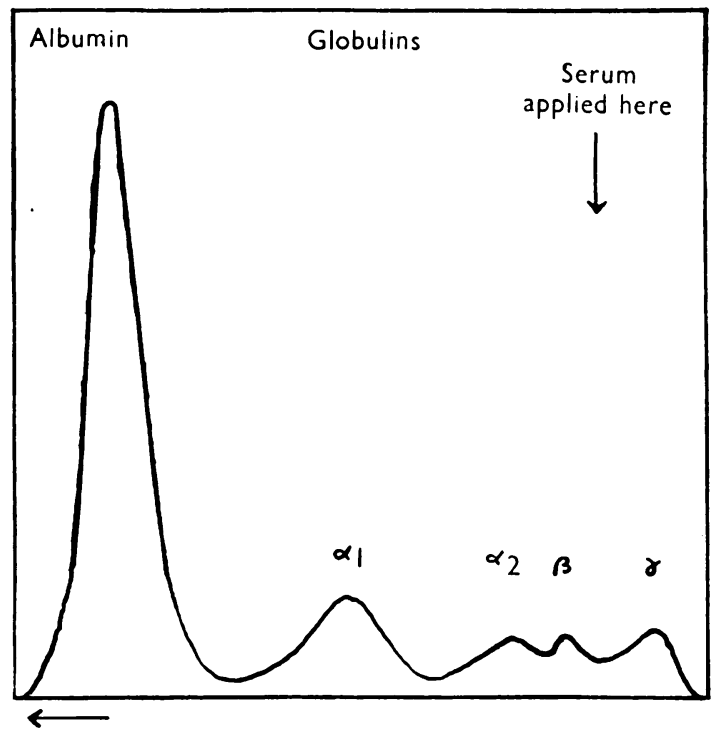

FIG. 2

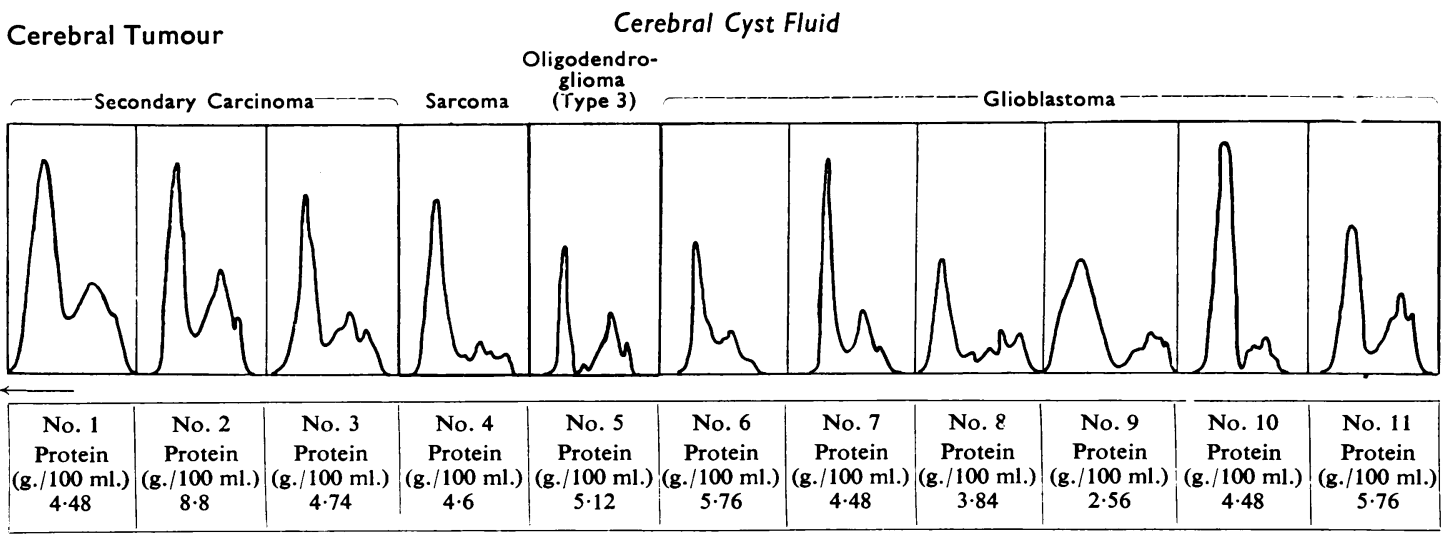

FIG. 3

\section{Cerebral Cyst Fluid}

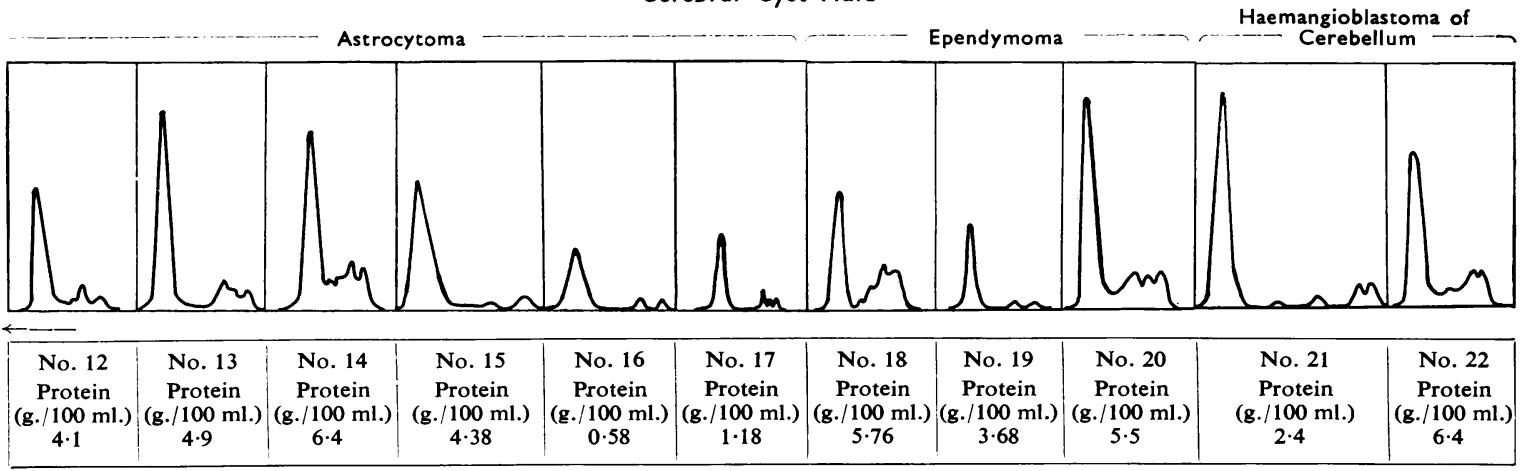

FIG. 4 
The quantity of each of these proteins is related to that area covered by the corresponding portions of the curve. When the patterns from cyst and cerebrospinal fluids are examined it will be seen that some of these components are absent, but that albumin and $\gamma$ globulin are always present. The $\alpha_{1}$ and $\alpha_{2}$ globulins are those that may be missing, of which the former is most frequently absent.

Some of the findings are shown in the accompanying charts. Fig. 3 shows the results seen in cerebral cyst fluids associated with tumours of the more malignant type such as glioblastoma, secondary carcinoma, a sarcoma, and a type 3 oligodendroglioma. For comparison Fig. 4 gives curves obtained from fluids from the more innocent tumours such as the astrocytoma and ependymoma. The results from fluids associated with a variety of other tumours are illustrated in Fig. 5. The most striking feature is the apparently large amount of $\beta$ globulin in the more malignant cases, and the relative absence of this protein in innocent cases. However, in only a few cyst fluids is a protein pattern similar to that of serum found, and this occurs in the cerebellar haemangioblastoma which, as I have shown earlier (1950), has a chemical composition analogous to that of serum.

Figs. 6, 7, and 8 illustrate the findings in the C.S.F. obtained from various disease processes. Many results obtained have been omitted, for in some diseases only single samples have been tested, and in others the patterns demonstrated show no features worthy of comment.

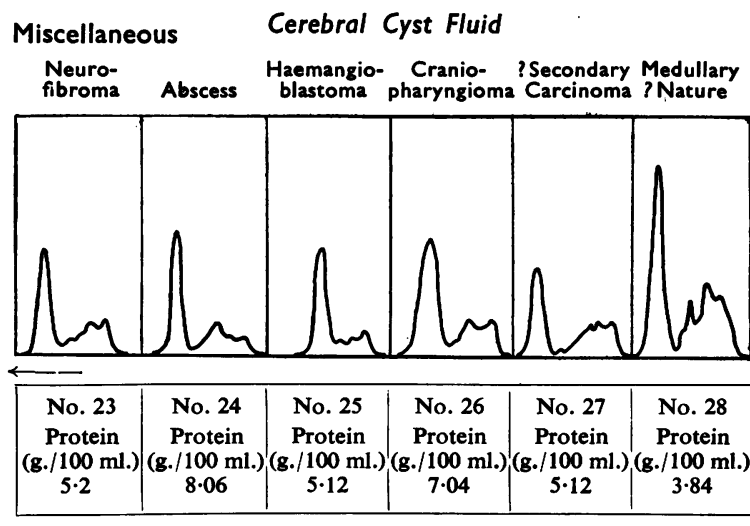

FIG. 5

\section{Discussion}

A few comments about the apparatus and the technique are needed. Various methods and types of apparatus were tried before finally using that described here, as all others were found to have various defects. The first technique used was that described by Schneider and Wallenius (1951) but this was discarded for reasons similar to those given by Flynn and de Mayo. The use of separate pairs of perspex jars was then tried and this was found to effect a saving of buffer, as only about $75 \mathrm{ml}$. of barbitone buffer need be used in each jar, so that should the need arise it is only necessary to change the buffer in one or two jars and not in the whole trough as used by Flynn and de Mayo. The use of a carbon rod as a positive electrode

Cerebrospinal Fluid

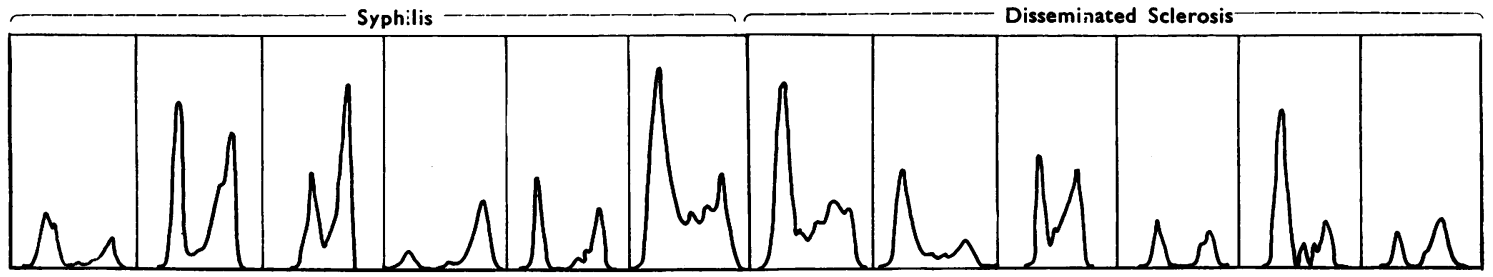

\begin{tabular}{|c|c|c|c|c|c|c|c|c|c|c|c|}
\hline No. 1 & No. 2 & No. 3 & No. 4 & No. 5 & No. 6 & No. 7 & No. 8 & No. 9 & No. 10 & No. 11 & No. 12 \\
\hline $\begin{array}{c}\text { Protein } \\
\text { (g. } / 100 \mathrm{ml} .)\end{array}$ & $\begin{array}{c}\text { Protein } \\
(\mathrm{g} . / 100 \mathrm{ml} .) \\
0.150\end{array}$ & $\begin{array}{c}\text { Protein } \\
(\mathrm{g} . / 100 \mathrm{ml} .) \\
0.080\end{array}$ & $\begin{array}{c}\text { Protein } \\
\text { (g. } / 100 \mathrm{ml} .) \\
0.050\end{array}$ & $\begin{array}{c}\text { Protein } \\
\text { (g. } / 100 \mathrm{ml} \text {.) } \\
0.050\end{array}$ & $\begin{array}{c}\text { Protein } \\
(\mathrm{g} . / 100 \mathrm{ml} .) \\
0.060\end{array}$ & $\begin{array}{c}\text { Protein } \\
\text { (g./100 ml.) } \\
0.090\end{array}$ & $\left(\begin{array}{c}\text { Protein } \\
(\mathrm{g} . / 100 \mathrm{ml} .) \\
0.080\end{array}\right)$ & $\left(\begin{array}{c}\text { Protein } \\
(\mathrm{g} . / 100 \mathrm{ml} .) \\
0.045\end{array}\right)$ & $\begin{array}{c}\text { Protein } \\
(\mathrm{g} . / 100 \mathrm{ml} .) \\
0.080\end{array}$ & $\begin{array}{c}\text { Protein } \\
(\mathrm{g} . / 100 \mathrm{ml} .) \\
0.080\end{array}$ & $\begin{array}{c}\text { Protein } \\
(\mathrm{g} . / 100 \mathrm{ml} .) \\
0.050\end{array}$ \\
\hline Tabes & $\begin{array}{c}\text { Meningo- } \\
\text { vascular }\end{array}$ & G.P.I. & G.P.I. & G.P.I. & $\begin{array}{l}\text { Meningo- } \\
\text { vascular }\end{array}$ & & & & & & \\
\hline $\begin{array}{c}\text { Lange } \\
\text { No change }\end{array}$ & $\begin{array}{c}\text { Lange } \\
0001122211\end{array}$ & $\begin{array}{c}\text { Lange } \\
5433321000\end{array}$ & $\begin{array}{c}\text { Lange } \\
5443221000\end{array}$ & $\begin{array}{c}\text { Lange } \\
5432221100\end{array}$ & $\begin{array}{c}\text { Lange } \\
3333221100\end{array}$ & $\begin{array}{c}\text { Lange } \\
0012210000\end{array}$ & $\begin{array}{c}\text { Lange } \\
0011221100\end{array}$ & $\begin{array}{c}\text { Lange } \\
5543211000\end{array}$ & $\begin{array}{c}\text { Lange } \\
3332211000\end{array}$ & $\begin{array}{c}\text { Lange } \\
5433321000\end{array}$ & $\begin{array}{c}\text { Lange } \\
\text { No change }\end{array}$ \\
\hline $\begin{array}{c}\text { W.R. } \\
-\end{array}$ & $\begin{array}{l}\text { W.R. } \\
+++\end{array}$ & $\begin{array}{c}\text { W.R. } \\
+++\end{array}$ & $\begin{array}{c}\text { W.R. } \\
\pm\end{array}$ & $\begin{array}{c}\text { W.R. } \\
+\end{array}$ & $\begin{array}{c}\text { W.R. } \\
\pm\end{array}$ & & & & & & \\
\hline
\end{tabular}

FIG. 6 


\section{Cerebrospinal Fluid}

Cerebral Tumour

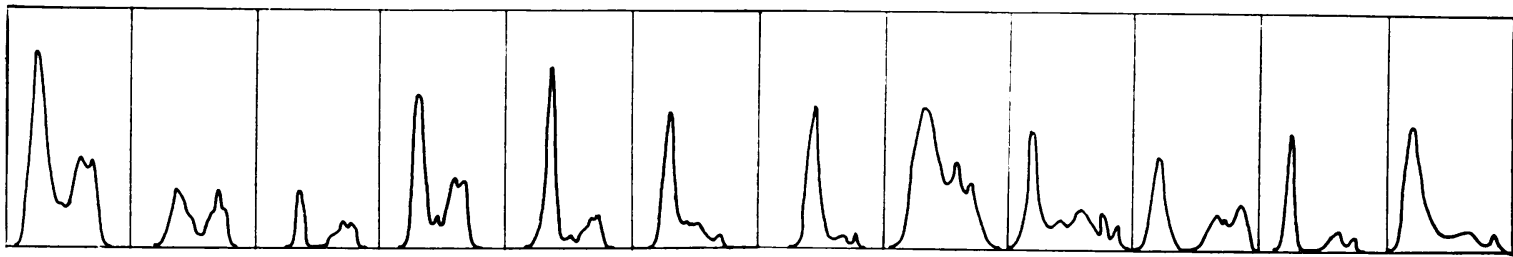

\begin{tabular}{|c|c|c|c|c|c|c|c|c|c|c|c|}
\hline No. 13 & No. 14 & No. 15 & No. 16 & No. 17 & No. 18 & No. 19 & No. 20 & No. 21 & No. 22 & No. 23 & No. 24 \\
\hline $\begin{array}{l}\text { Protein } \\
\text { (g. } / 100 \mathrm{ml} .)\end{array}$ & $\begin{array}{c}\text { Protein } \\
\text { (g. } / 100 \mathrm{ml} .)\end{array}$ & $\begin{array}{c}\text { Protein } \\
(\mathrm{g} . / 100 \mathrm{ml} .)\end{array}$ & $\begin{array}{c}\text { Protein } \\
\text { (g. } / 100 \mathrm{ml} \text {.) }\end{array}$ & $\begin{array}{c}\text { Protein } \\
\text { (g. } / 100 \mathrm{ml} .)\end{array}$ & $\begin{array}{l}\text { Protein } \\
\text { (g. } / 100 \mathrm{ml} .)\end{array}$ & $\begin{array}{c}\text { Protein } \\
\text { (g. } / 100 \mathrm{ml} .)\end{array}$ & $\begin{array}{c}\text { Protein } \\
(\text { g. } / 100 \mathrm{ml} .)\end{array}$ & $\begin{array}{c}\text { Protein } \\
(\text { g. } / 100 \mathrm{ml} .)\end{array}$ & $\begin{array}{c}\text { Protein } \\
\text { (g. } / 100 \mathrm{ml} .)\end{array}$ & $\begin{array}{c}\text { Protein } \\
(\mathrm{g} . / 100 \mathrm{ml} .)\end{array}$ & $\begin{array}{c}\text { Protein } \\
\text { (g. } / 100 \mathrm{ml} .)\end{array}$ \\
\hline $0 \cdot 100$ & 0.090 & 0.015 & $\begin{array}{c}0.140 \\
0.1\end{array}$ & $2 \cdot 8$ & 0.320 & 1.800 & $2 \cdot 18$ & 0.120 & 0.500 & 0.090 & 0.070 \\
\hline $\begin{array}{c}\text { Nature } \\
\text { unknown }\end{array}$ & $\begin{array}{c}\text { Nature } \\
\text { unknown }\end{array}$ & $\begin{array}{l}\text { Choroid } \\
\text { papilloma }\end{array}$ & $\begin{array}{c}\text { Glio- } \\
\text { blastoma }\end{array}$ & Glioma & $\begin{array}{l}\text { Neuro- } \\
\text { fibroma }\end{array}$ & $\begin{array}{c}\text { Glio- } \\
\text { blastoma }\end{array}$ & $\begin{array}{c}\text { Glio- } \\
\text { blastoma }\end{array}$ & Glioma & $\begin{array}{l}\text { Neuro- } \\
\text { fibroma }\end{array}$ & $\begin{array}{c}\text { Nature } \\
\text { unknown }\end{array}$ & Sarcoma \\
\hline
\end{tabular}

Fig. 7

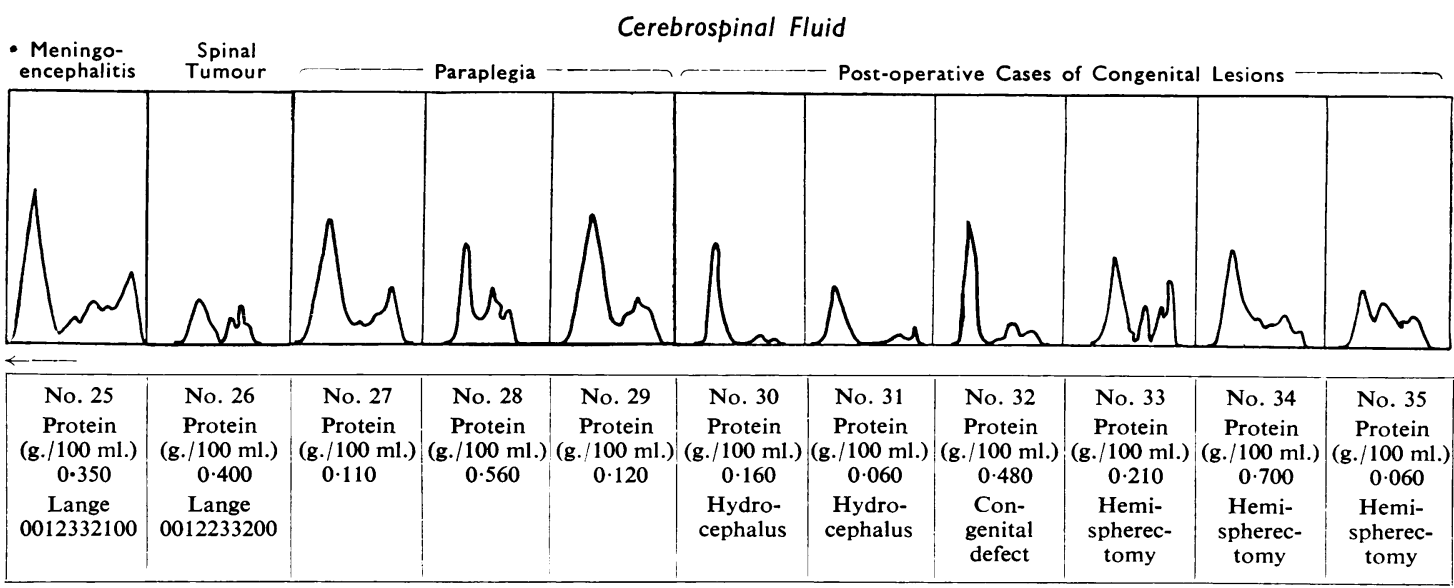

FIG. 8

always resulted in the buffer rapidly deteriorating with fragments of carbon in it, whereas the use of a platinum wire electrode obviated this disadvantage and rendered changing of the buffer to be less frequent.

Anisole was used at one time to render the paper strip translucent, but this meant that the paper could not be dried, whereas with the solution recommended here the strips can be dried, and provided they are stored in the dark, they can be kept for long periods without alteration or loss of colour.

It is at once obvious on consideration of the results obtained from cerebral cyst fluids that the protein patternst. do not resemble those seen with serum, except in two conditions. When a cyst has once been tapped it may fill again fairly rapidly and the fluid obtained at later punctures more closely resembles serum in character. The other exception is in the fluid from a cerebellar cyst associated with a haemangioblastomatous nodule in the wall. These findings agree with an opinion expressed earlier following chemical analysis in which the cyst fluid in such cases apparently originated from serum (Cumings, 1950). It was also noticed then that the albumin content of the cyst fluid was relatively low when compared with the total protein, more especially in the malignant group, and the present work explains this anomaly, for in this group, as can be seen from Fig. 3, there is a relative increase in the globulin portion, more especially in the $\beta$ globulin, or at least in a zone occupied by that fraction in normal serum. It is not yet possible to state with certainty whether this increased globulin 
is derived from the blood or from the tumour, but preliminary experiments on extracts from tumour tissue suggest the latter as a distinct possibility, for in two such experiments a $\beta$ globulin and a trace only of $\alpha$ globulin and of albumin were obtained, but further work is needed along these lines. Meanwhile, the presence of this increased protein may be of some diagnostic value in the examination of cerebral cyst fluids, for even though it has been seen in some of the other records the diagnosis in these cases is unknown or uncertain, and it may well be that the tumours in these cases were also actively growing or malignant in nature, as was in fact true in two instances.

Consideration of the results found in C.S.F. at once make it clear that the protein patterns of these pathological fluids are not similar to those of serum, even though Wallenius (1952) found patterns in normal fluids similar to those of serum. Labhart and others (1951), however, found a higher albumin globulin ratio in the C.S.F. compared with blood serum. Pathological conditions certainly alter the proteins and there are striking examples of this, particularly in cases of cerebral tumour, syphilis, and disseminated sclerosis. The results in the fluid from cases of cerebral tumour seen in Fig. 7 immediately recall the results seen in cyst fluids from malignant tumours. The protein patterns in some of these cerebrospinal fluids also show that $\beta$ globulin is relatively abundant and that it is more frequently seen when the tumour is malignant. This, too, may prove of some diagnostic value.

The fluids in cases of syphilis and disseminated sclerosis are most interesting and they show a considerable excess of $\gamma$ globulin, and in some cases of syphilis there is obviously more globulin than albumin, a fact which is not in accord with the statement of Walshe (1952) that this never occurs. It is also a little remarkable that $\gamma$ globulin is more abundant in syphilis than in disseminated sclerosis, while it is noteworthy that an increase in this globulin by itself does not parallel the Lange curve exactly, and in a number of cases the Lange curve is paretic with relatively low $\gamma$ globulin; the reverse is also seen. These findings are in agreement with those of Labhart and others who were using a different technique.

Fluids from meningo-encephalitis showed rather unexpected results which cannot be explained. The fluids from lesions following damage to the spinal cord, as well as a case of spinal tumour, have given abnormal protein patterns showing increased $\gamma$ and $\beta$ globulin, and these results are unlike those that could be produced by transudation of fluid from serum, as has been postulated.

Fig. 8 shows the results from fluids obtained post-operatively, and in many of these cases there had been some blood in the C.S.F. previously; accordingly the patterns tend to be similar to those of serum.

Some fluids after concentration were kept for some days in the refrigerator and also at room temperature, and for one week no alteration in pattern from the original was seen at either temperature. Only one fluid, kept at room temperature for eight days, showed a small area of additional staining beyond the albumin, but in no other fluideither lumbar or ventricular-was this found, and it is felt that alteration of the protein may have taken place.

A number of sera have been examined in parallel with the C.S.F. or cyst fluid from the same patient, and in almost every case the patterns were different. One exception was seen in a patient with a glioblastoma in whom the serum also showed a relatively raised $\beta$ globulin.

Little attempt has been made to measure thes amounts of each component protein as it is generallyo agreed that such results do not parallel those obtained by the classical Tiselius method. However, in some cases this has been done and it may be off value in following treatment in syphilis, but usually a visual impression of the shape of the pattern is adequate for ordinary diagnostic purposes.

\section{Summary}

The results of the examination of the proteins of 70 cerebrospinal fluids and 45 cerebral cyst fluids by means of paper strip electrophoresis are recorded.

No correlation between the pattern of the serum proteins and those of the materials examined was obtained except for cyst fluids associated with cerebellar haemangioblastoma, and in cerebrospinal fluids from meningitis and post-operative conditions in which blood had been mixed with the fluid.

An excess of globulin in the position of the $\beta$ component in serum was found in both cyst fluids and cerebrospinal fluids from cases of malignant tumours, and also in two cases from tumour tissue itself.

The Lange reaction did not exactly parallel the amount of $\gamma$ globulin in syphilis or in disseminated sclerosis. 
My sincere thanks are due to the physicians and surgeons who supplied me with suitable material, to Dr. W. Blackwood and Prof. T. Crawford for their histological opinions, and to Dr. D. Richardson and the Photographic Department of the Institute of Neurology for the photograph of the apparatus.

I also desire to thank Messrs. Dextran Ltd. and Messrs. May \& Baker Ltd. for their gifts of " dextran" and "polyvinylpyrrolidone" respectively.

\section{REFERENCES}

Cumings, J. N. (1950). Brain, 73, 244.

Flynr, F. V., and Mayo, P. de (1951). Lancet, 2, 235.

Labhart, H., Schweizer, W., and Staub, H. (1951). Confin. neurol., Basel, 11, 325.

Schaltenbrand, G. (1952). Personal communication.

Schneider, G., and Wallenius, G. (1951). Scand. J. clin. Lab. Invest., 3,145 .

Wallenius, G. (1952). Acta Soc. Med. upsalien., 57, 138.

Walshe, F. M. R. (1952). Diseases of the Nervous System, 7th Ed., p. 56. Livingstone, Edinburgh. 